\title{
Empirical Analysis on Regional Economic Growth from the Perspectives of Entrepreneurship and Investment in Research and Development
}

\author{
Hongmei Chen, Min Liang* \\ School of Economics and Management of Qiqihar University, Qiqihar 161006, China
}

Corresponding Author Email: 02331@qqhru.edu.cn

https://doi.org/10.18280/ijsdp.150812

Received: 15 July 2020

Accepted: 1 October 2020

\section{Keywords:}

regional economic growth (REG), entrepreneurship, investment in research and development $(R \& D)$, fixed effects model

\begin{abstract}
This paper mainly assesses the influence of entrepreneurship over regional economic growth (REG) and the investment in research and development (R\&D), and puts forward countermeasures to promote the REG. The fixed effects model for panel data analysis was adopted to evaluate how entrepreneurship directly affects REG and indirectly affects REG via R\&D investment. The results show that the entrepreneurial and innovative spirits of entrepreneurs promote economic growth; the promoting effect of entrepreneurial spirit is greater than that of innovative spirit; R\&D investment mediates the influence of entrepreneurship over economic growth; the three major economic regions of China, namely, East, Central, and West China, have different laws in the influence of entrepreneurial spirit and innovative spirit on economic growth and R\&D investment, owing to the variation in resources endowment and entrepreneurship allocation. The research results help policymakers formulate regional economic development strategies in the light of entrepreneurship configuration and R\&D investment.
\end{abstract}

\section{INTRODUCTION}

The rapid development of China's economy has attracted the attention of the world. But the economic development is troubled by problems like regional imbalance and widening income gap. Many scholars have interpreted economic development from different angles. Schumpeter (1934) treated the innovation and entrepreneurial activities of entrepreneurs, an important subject of economic activities, as the driver of economic sustainability. The endogenous growth theory agrees that national economic growth is driven by endogenous technological progress, which is in turn energized by innovation. Through arbitrage, entrepreneurship promotes economic growth, and improves resource allocation and innovation, thereby advancing technological progress. In fact, technological innovation is the only path for entrepreneurship to enhance economic sustainability. The promoting effect of entrepreneurship on economic development is realized through the dynamic allocation of production factors and the optimized decision-making of technological innovation. The economic development of a region is positively correlated with the entrepreneurship level [1]. Considering the importance of entrepreneurship to economic development, the academia has directed its gaze to how entrepreneurship affects economic development.

The relationship between entrepreneurship and economic growth has been studied extensively. Despite the lack of consensus, most empirical studies indicate that entrepreneurship is beneficial to economic growth. Under the changes of global economy, the status of entrepreneurship has varied significantly, and entrepreneurship is increasingly regarded as a promoter of economic growth [2]. The full display and effective configuration of entrepreneurship form a dynamic mechanism to promote economic development [3]. In addition, it is widely agreed that entrepreneurs play an important role in promoting economic development. To realize rapid expansion, the founders of small and mediumsized enterprises (SMEs) must have reasonable entrepreneurial orientations [4]. The entrepreneurship of entrepreneurs, especially that of young entrepreneurs, greatly promotes the development of the national economy [5].

The impact mechanism of entrepreneurship on economic growth has been a research hotspot. For example, Tang and Hela and Daniele [6] suggested that innovative and entrepreneurial spirits are key drivers of the diversification and growth of economies in the Gulf Cooperation Council (GCC). Hashi and Krasniqi [7] compared three developed countries in Central and Eastern Europe and three underdeveloped countries in Southeastern Europe, and discovered the significant promoting effect of entrepreneurial and innovative features of enterprises on the growth of SMEs.

So far, the role of entrepreneurship in promoting economic growth has been repeatedly affirmed through the abundant research on the relationship between entrepreneurship and economic growth, and that between investment in research and development (R\&D) and economic growth. The relevant research also explores how the promotion of entrepreneurship on economic development is regulated by various factors, such as social capital, social security, and degree of marketization. However, few studies have discussed the indirect influence of entrepreneurship on economic growth via R\&D investment. To promote the high-quality growth of the Chinese economy, this paper splits entrepreneurship into two dimensions, namely, innovative spirit and entrepreneurial spirit, and introduces the variables of $R \& D$ investment to analyze the direct promotion of economic growth by different dimensions of 
entrepreneurship, as well as the indirect impact via R\&D investment. In this way, the authors thoroughly evaluated the impact of the differentiated configuration of entrepreneurship, and provided a reference for policy-makers to formulate regional economic development strategies in the light of entrepreneurship configuration and $\mathrm{R} \& \mathrm{D}$ investment.

The rest of this paper consists of four sections: Section 2 puts forward several hypotheses based on theoretical analysis and relevant literature; Section 3 details the research design, including samples, data sources, variables, and evaluation models; Section 4 empirically evaluates the degree and direction of the impact of entrepreneurship on REG via R\&D investment, analyzes the regional differences in the impact, and tests the robustness of the analysis results; Section 5 summarizes the conclusions, and presents countermeasures to promote REG.

\section{HYPOTHESES}

\subsection{Entrepreneurship and economic growth}

Since Cantillon introduced the concept of entrepreneurs into the economic field, researchers around the world have explored the meaning, dimensions, and functions of entrepreneurship from multiple angles. Drawing on the findings of Hebert and Link [8], Mthantihe and Ojah [9], entrepreneurship was divided into entrepreneurial spirit and innovative spirit.

Many studies have demonstrated the correspondence between the level of entrepreneurship and the speed and quality of economic development. Entrepreneurship creates a good internal and external environment for the establishment of enterprises. This environment favors employment and income growth. The resulting spillover effect promotes urban economic growth [10]. Entrepreneurs' foresight, pursuit of achievement, attitude towards risk and self-confidence and other unique characteristics motivate entrepreneurs to carry out innovation and entrepreneurial activities [11]. Adusei [12] proved that even copy entrepreneurship drives economic growth. Belitski and Desai [13] suggested that entrepreneurship promotes creativity spillover, and empirically studied the promoting effect of entrepreneurship on economic development in 15 countries and regions in Europe. In summary, it is widely agreed that entrepreneurship promotes economic growth. On this basis, the following hypotheses were presented:

H1a: The entrepreneurial spirit of entrepreneurs has a positive effect on economic growth;

H1b: The innovative spirit of entrepreneurs has a positive effect on economic growth.

\subsection{Entrepreneurship and $R \& D$ investment}

Schumpeter was the first to discuss the relationship between entrepreneurs and innovation activities. As the main advocator of innovation activities, entrepreneurship permeates the decision-making related to corporate $\mathrm{R} \& \mathrm{D}$ activities. Through a sample analysis on the enterprises in the Organization for Economic Co-operation and Development (OECD), Guellec et al. [14] observed that enterprises, as the subject of innovation, bear most of the expenditure of national scientific research, and learned that the innovation decisions of entrepreneurs determine the amount, direction, and structure of corporate $R \& D$ investment, affect the $R \& D$ investment effect, and bear on the speed and efficiency of economic growth. Baumol [15] believed that the amount of R\&D investment is affected by the entrepreneurs' decisions on innovation activities. Entrepreneurship promotes the R\&D investment, but the promoting effect weakens with the increase of rent-seeking; corporate $\mathrm{R} \& \mathrm{D}$ investment depends on the entrepreneurs' decision-making, which hinges on entrepreneurship. To sum up, entrepreneurship affects the decision-making on innovation activities, and thus determines the level of corporate R\&D investment. On this basis, the following hypotheses were presented:

H2a: The entrepreneurial spirit of entrepreneurs has a positive effect on R\&D investment;

$\mathrm{H} 2 \mathrm{~b}$ : The innovative spirit of entrepreneurs has a positive effect on R\&D investment.

\subsection{Mediating role of $R \& D$ investment}

Economic growth could be promoted by various factors. The most effective among them is the R\&D activities carried out by countries. The scale of these activities can be accurately measured by the $R \& D$ expenditure [16]. $R \& D$ investment is a major and long-lasting promoter of economic growth, and the promoting effect varies in the region and the surrounding areas There is a positive correlation between government fiscal R\&D investment and economic growth. To bolster economic growth, the government can stimulate R\&D investment by implementing fiscal policies [17]. Increasing R\&D investment is conducive to expanding the scale of economic development and spurring economic growth.

During economic growth, entrepreneurs are an important subject of resource allocation. The entrepreneurial entrepreneurs are highly sensitive to economic development opportunities, and capable of adjusting the resource allocation in time. The innovation and entrepreneurial activities of entrepreneurs are motivated by unique features, such as foresight, pursuit of achievement, attitude towards risk, and self-confidence [18]. The entrepreneurial activities help to expand the scale or number of enterprises, and intensity market competition, leading to more innovation activities by entrepreneurs. Entrepreneurial and innovation activities can push up R\&D investment, the allocation efficiency of innovative resources, as well as the growth of enterprises and REG. The stimulation of economic growth by entrepreneurship is realized through the impact on the flow and spillover of knowledge, and the triggering of technological innovation and progress.

Entrepreneur is the key impactor of R\&D investment. For an enterprise, the intensity of R\&D investment affects the core competitiveness and sustainable development. The R\&D investment, which is affected by entrepreneurship, work with entrepreneurship to determine the rate of economic growth [19]. As a result, entrepreneurs have become a crucial factor of success. They can and create new products, implement new technologies, and develop and innovate new services, making immense contributions to economic growth [2]. On this basis, the following hypotheses were presented:

H3a: R\&D investment mediates the relationship between entrepreneurial spirit of entrepreneurs and economic growth;

H3b: R\&D investment mediates the relationship between innovative spirit of entrepreneurs and economic growth.

In summary, the research framework is established as shown in Figure 1. 


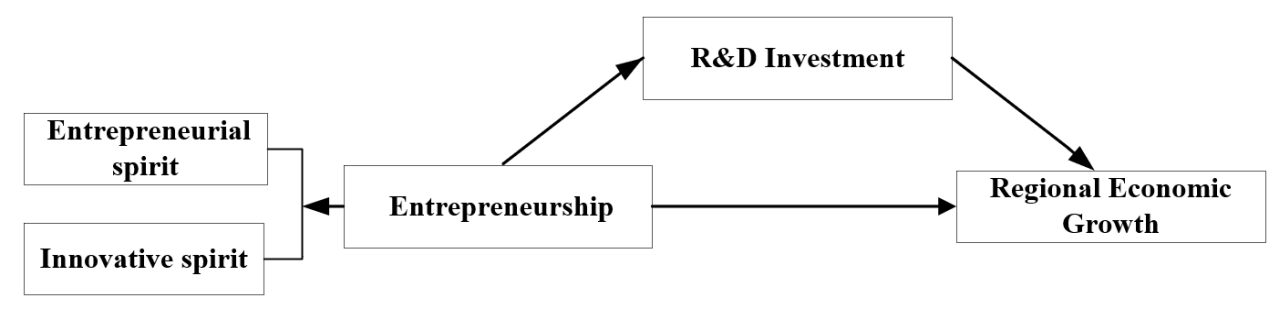

Figure 1. The research framework

\section{RESEARCH DESIGN}

\subsection{Sampling and data sources}

30 provincial administrative regions (PARs) in Chinese mainland were selected as the samples for empirical analysis on the influence of entrepreneurship on R\&D investment and economic growth. Tibet was eliminated for the incompleteness of data. The original data were collected from China Statistical Yearbooks 2001-2019, China Statistics Yearbooks on Science and Technology 2001-2019, China Basic Statistical Units Yearbooks 2001-2019, China Compendium of Statistics 19492008, and The Wind Economic Database. The original data were rounded by $1 \%$ to eliminate the negative effects of extreme values on analysis results.

\subsection{Variables}

\section{(1) Explained variable}

REG, as the explained variable, was measured by the regional gross domestic product (RGDP) (Tgdp). Taking 2000, the first year of the original data as the base period, the GDP of each PAR in China was converted into real GDP, reflecting the actual economic growth rate excluding the effect of fluctuating price.

\section{(2) Explanatory variable}

Entrepreneurship (ES) was decomposed into entrepreneurial spirit and innovative spirit. Referring to the relevant literature and the availability of data, the entrepreneurial spirit was measured by the number of employees in private enterprises as a percentage of the total number of employees (Pee), and the innovative spirit was measured by the number of patent applications $(\mathrm{Paa})$.

(3) Intermediary variable

R\&D investment $(R d)$, as the intermediary variables, was measured by the internal expenditure of research funds of each PAR.

(4) Control variables

Besides entrepreneurship and R\&D investment, many factors have an impact on economic growth. For comprehensive analysis, multiple control variables were selected: government regulation (Gov), measured by the ratio of government fiscal expenditure to regional GDP; openingup $(F d i)$, measured by the ratio of foreign direct investment (FDI) to regional GDP; human capital quality $(H c)$, calculated by (the number of primary school graduates $* 6+$ the number of junior high school graduates $* 9+$ the number of senior high school graduates $* 12+$ the number of graduates from junior college and above * 16)/ the number of population aged 6 and above); financial development (Fir), measured by the ratio of the total deposit and loan balance of financial institutions to regional GDP; infrastructure construction (Il), calculated by the total investment in fixed asset / regional GDP.

\subsection{Model construction}

As a classic production function model, the Cobb-Douglas (C-D) production function measures the relationship between inputs and outputs in economic development. It is widely used to analyze economic growth. This paper takes entrepreneurship $(E S)$ and $\mathrm{R} \& \mathrm{D}$ investment $(R d)$ as production inputs, and introduces them into the $\mathrm{C}-\mathrm{D}$ production function, creating a dynamic evaluation model:

$$
Y=A L^{\alpha} K^{\beta} E S^{\gamma} R d^{\delta} e^{\theta}
$$

To mitigate the impact of heteroscedasticity, the logarithm was taken on both sides of formula (1), and the control variables, including government regulation (Gov), opening-up (Fdi), financial development (Fir), human capital quality $(H c)$, and infrastructure construction, were imported. Drawing on Wen et al.'s intermediary model, the following model can be established:

$$
\begin{gathered}
\ln Y_{i t}=\beta_{0}+\beta_{1} \ln L_{i t}+\beta_{2} \ln K_{i t}+\beta_{3} \ln E S_{i t}+ \\
\beta_{4} \ln G o v_{i t}+\beta_{5} \ln F d i_{i t}+\beta_{6} \ln H c_{i t}+ \\
\beta_{7} \ln F i r_{i t}+\beta_{8} \ln I l_{i t}+\varepsilon_{i t} \\
\ln R d_{i t}=\beta_{0}+\beta_{1} \ln L_{i t}+\beta_{2} \ln K_{i t}+\beta_{3} \ln E S_{i t}+ \\
\beta_{4} \ln G o v_{i t}+\beta_{5} \ln F d i_{i t}+\beta_{6} \ln H c_{i t}+ \\
\beta_{7} \ln F i r_{i t}+\beta_{8} \ln I l_{i t}+\varepsilon_{i t} \\
\ln Y_{i t}=\beta_{0}+\beta_{1} \ln L_{i t}+\beta_{2} \ln K_{i t}+\beta_{3} \ln E S_{i t}+ \\
\beta_{4} \ln R d_{i t}+\beta_{5} \ln G o v_{i t}+\beta_{6} \ln F d i_{i t}+ \\
\beta_{7} \ln H c_{i t}+\beta_{8} \ln F i r_{i t}+\beta_{9} \ln I l_{i t}+\varepsilon_{i t}
\end{gathered}
$$

where, $\mathrm{Y}$ is the REG; $i$ and $t$ are the serial number of PAR and year, respectively; $\beta_{0}-\beta_{9}$ are model parameters; $\varepsilon_{i t}$ is the interference term; $\mathrm{L}$ is the labor input, measured by the labor population $(L f) ; \mathrm{K}$ is the capital input, measured by the capital stock estimated by the permanent inventory method $(S c)$.

According to relevant research, the price index of fixed asset investment in most China's PARs changed significantly after 1978. Hence, the annual fixed asset investment was measured by the total fixed asset formation with 1978 as the base period. Some missing values were replaced by the similar index of fixed asset investment amount. Referring to related research results, the depreciation rate was set to $9.6 \%$ [20].

Model 2 aims to test the influence of entrepreneurial spirit and innovation spirit over economic growth. Model 3 aims to test the influence of entrepreneurial spirit and innovation spirit over R\&D investment. Model 4 aims to test the mediating role of R\&D investment on the influence of entrepreneurial spirit and innovation spirit over economic growth.

Based on the economic situation of Chinese mainland, the differential influence of entrepreneurship on R\&D investment and economic growth among East, Central, and West China. 


\section{EMPIRICAL ANALYSIS}

\subsection{Descriptive analysis}

Table 1 gives the descriptive statistics of the main variables. It can be seen that the log value of actual RGDP ( $T g d p)$ was maximized at 10.877 , and minimized at 5.804, indicating the huge gaps between PARs in economic growth. For the log value of entrepreneurial spirit ( $P e e$ ), the maximum, minimum, media, mean, and standard deviation were $2.294,-2.403$, $0.106,-0.014$, and 1.026 , respectively, reflecting the large regional differences in entrepreneurial spirit and the overall low level of that spirit. For the log value of innovative spirit $(\mathrm{Paa})$, the maximum, minimum, and standard deviation were $13.314,5.375$, and 1.710, respectively, suggesting that different PARs differ greatly in this spirit. For the log value of R\&D investment (Rd), the maximum, minimum, and standard deviation were $7.614,0.258$, and 1.644 , respectively, showing the large PAR discrepancy in internal R\&D expenditure.
Table 1. The descriptive statistics of the main variables

\begin{tabular}{|c|c|c|c|c|}
\hline \multicolumn{5}{|c|}{ Variables $N$ Mean Sd Med Min Max } \\
\hline $\ln$ Tgdp & 5708.7361 .07 & 8.832 & 5.804 & \\
\hline $\ln \mathrm{Lf}$ & 5707.8470 .7 & & 5.939 & .039 \\
\hline & 5707.8610 .86 & 7.990 & 4.6 & 9.346 \\
\hline $\ln \_$Pee & $570-0.1141 .026$ & -0.10 & -2.4 & 2.294 \\
\hline ln_Paa & 5709.4491 .71( & 9.442 & 5.3 & 13.134 \\
\hline ln_Rd & 5704.4491 .6 & 4.574 & 0.258 & 7.614 \\
\hline $\ln$ Gov & 5702.9160 .426 & 2.921 & 2.037 & 4.066 \\
\hline $\ln$ Fir & 5700.9680. & .95 & 0.3 & 2.016 \\
\hline
\end{tabular}

\subsection{Regression analysis}

\subsubsection{Entrepreneurship, R\&D investment, and REG}

Substituting the indices of entrepreneurial and innovative spirits into the above model, the fixed effects model for panel data analysis was adopted to empirically evaluate the influence of entrepreneurship on R\&D investment and REG through Hausman test. The evaluation results are recorded in Table 2.

Table 2. The regression results on entrepreneurship, R\&D investment, and REG

\begin{tabular}{|c|c|c|c|c|c|c|c|}
\hline Variables & (1) & (2) & (3) & (4) & (5) & (6) & (7) \\
\hline vallavies & Tgdp & Tgdp & $\mathrm{Rd}$ & $\mathrm{Rd}$ & Tgdp & Tgdp & Tgdp \\
\hline ln_Lf & $\begin{array}{c}0.234 * * * \\
(6.57)\end{array}$ & $\begin{array}{c}0.159 * * * \\
(4.48)\end{array}$ & $\begin{array}{c}0.384 * * * \\
(4.62)\end{array}$ & $\begin{array}{c}0.282 * * * \\
(3.58)\end{array}$ & $\begin{array}{c}0.100 * * * \\
(2.73)\end{array}$ & $\begin{array}{c}0.143 * * * \\
(4.73)\end{array}$ & $\begin{array}{c}0.098^{* * *} \\
(3.11)\end{array}$ \\
\hline ln_Sc & $\begin{array}{c}0.638^{* * *} \\
(21.42)\end{array}$ & $\begin{array}{c}0.733 * * * \\
(28.12)\end{array}$ & $\begin{array}{c}1.353 * * * \\
(19.51)\end{array}$ & $\begin{array}{c}1.351 * * * \\
(23.43)\end{array}$ & $\begin{array}{c}0.463 * * * \\
(12.32)\end{array}$ & $\begin{array}{c}0.318^{* * *} \\
(9.76)\end{array}$ & $\begin{array}{c}0.442 * * * \\
(13.52)\end{array}$ \\
\hline ln_Pee & $\begin{array}{c}0.309^{* * *} \\
(18.79)\end{array}$ & & $\begin{array}{c}0.337 * * * \\
(8.80)\end{array}$ & & & $\begin{array}{c}0.229 * * * \\
(15.60)\end{array}$ & \\
\hline ln_Paa & & $\begin{array}{c}0.198 * * * \\
(19.10)\end{array}$ & & $\begin{array}{c}0.283 * * * \\
(12.36)\end{array}$ & & & $\begin{array}{c}0.137 * * * \\
(13.23)\end{array}$ \\
\hline Ln_Rd & & & & & $\begin{array}{c}0.323 * * * \\
(18.45)\end{array}$ & $\begin{array}{c}0.237 * * * \\
(15.23)\end{array}$ & $\begin{array}{c}0.215^{* * *} \\
(12.48)\end{array}$ \\
\hline ln_Gov & $\begin{array}{c}0.208^{* * *} * \\
(5.59)\end{array}$ & $\begin{array}{c}0.180 * * * \\
(4.83)\end{array}$ & $\begin{array}{c}0.415^{* * * *} \\
(4.78)\end{array}$ & $\begin{array}{c}0.357 * * * \\
(4.34)\end{array}$ & $\begin{array}{c}0.107 * * * \\
(2.78)\end{array}$ & $\begin{array}{c}0.110^{* * *} \\
(3.46)\end{array}$ & $\begin{array}{c}0.103 * * * \\
(3.09)\end{array}$ \\
\hline ln_Fir & $\begin{array}{l}0.050 \\
(1.28)\end{array}$ & $\begin{array}{l}-0.002 \\
(-0.04)\end{array}$ & $\begin{array}{c}0.211^{* *} \\
(2.29)\end{array}$ & $\begin{array}{l}0.066 \\
(0.74)\end{array}$ & $\begin{array}{c}0.116^{* * *} \\
(2.98)\end{array}$ & $\begin{array}{l}0.001 \\
(0.02)\end{array}$ & $\begin{array}{l}-0.016 \\
(-0.45)\end{array}$ \\
\hline ln_Fdi & $\begin{array}{c}-0.079 * * * \\
(-6.32)\end{array}$ & $\begin{array}{c}-0.027^{* *} \\
(-2.19)\end{array}$ & $\begin{array}{c}-0.117 * * * \\
(-4.02)\end{array}$ & $\begin{array}{c}-0.058^{* *} \\
(-2.16)\end{array}$ & $\begin{array}{l}-0.011 \\
(-0.88)\end{array}$ & $\begin{array}{c}-0.051 * * * \\
(-4.84)\end{array}$ & $\begin{array}{l}-0.014 \\
(-1.32)\end{array}$ \\
\hline ln_Hc & $\begin{array}{l}0.131^{*} \\
(1.85)\end{array}$ & $\begin{array}{l}0.089 \\
(1.26)\end{array}$ & $\begin{array}{l}0.257 \\
(1.56)\end{array}$ & $\begin{array}{l}0.149 \\
(0.95)\end{array}$ & $\begin{array}{l}0.140^{*} \\
(1.96)\end{array}$ & $\begin{array}{l}0.070 \\
(1.19)\end{array}$ & $\begin{array}{l}0.057 \\
(0.92)\end{array}$ \\
\hline ln_Il & $\begin{array}{l}0.001 \\
(0.03)\end{array}$ & $\begin{array}{c}0.046^{* *} \\
(2.23)\end{array}$ & $\begin{array}{l}0.092^{*} \\
(1.86)\end{array}$ & $\begin{array}{c}0.121 \text { *** } \\
(2.65)\end{array}$ & $\begin{array}{l}0.039^{*} \\
(1.87)\end{array}$ & $\begin{array}{l}-0.021 \\
(-1.19)\end{array}$ & $\begin{array}{l}0.020 \\
(1.09)\end{array}$ \\
\hline cons & $\begin{array}{c}0.885^{* *} \\
(2.54)\end{array}$ & $\begin{array}{c}-1.070 * * * \\
(-3.65)\end{array}$ & $\begin{array}{c}-11.639^{* * *} \\
(-14.31)\end{array}$ & $\begin{array}{c}-13.038 * * * \\
(-20.11)\end{array}$ & $\begin{array}{c}1.983 * * * \\
(5.04)\end{array}$ & $\begin{array}{c}3.639 * * * \\
(10.61)\end{array}$ & $\begin{array}{c}1.736^{* * *} \\
(5.08)\end{array}$ \\
\hline $\mathrm{N}$ & 570 & 570 & 570 & 570 & 570 & 570 & 570 \\
\hline $\mathrm{R}^{2}$ & 0.978 & 0.978 & 0.960 & 0.964 & 0.977 & 0.984 & 0.983 \\
\hline
\end{tabular}

To test the mediating role of $\mathrm{R} \& \mathrm{D}$ investment between entrepreneurship and economic growth, the indices of entrepreneurial spirit, innovation spirit, and REG were substituted into the regression model, respectively. According to the results of Model 1 and Model 2, the regression coefficients of entrepreneurial spirit and innovative spirit were 0.309 and 0.198 , respectively, indicating that both significantly promote REG. Thus, H1a and H1b were proved valid. Comparatively, entrepreneurial spirit has a greater promoting effect on REG than innovative spirit. Next, the influence of entrepreneurial spirit and innovative spirit on the intermediary variable of $R \& D$ investment was subject to regression analysis. According to the results of Model 3 and Model 4 , every $1 \%$ increase in entrepreneurial spirit promoted $\mathrm{R} \& \mathrm{D}$ investment by $0.337 \%$, while every $1 \%$ increase in innovative spirit promoted R\&D investment by $0.198 \%$, and the promoting effect was significant at the $1 \%$ level. Thus, $\mathrm{H} 2 \mathrm{a}$ and $\mathrm{H} 2 \mathrm{~b}$ were proved valid. Finally, the intermediary role of $R \& D$ investment between entrepreneurial and innovation spirits and REG was verified. According to the results of Model 5, every $1 \%$ increase in R\&D investment promoted RGDP by $0.323 \%$, and the promoting effect was significant at the $1 \%$ level. According to the results of Models 6 and 7 , the coefficients of entrepreneurial spirit, innovative spirit, and $R \& D$ investment were significantly positive; the coefficient of entrepreneurial spirit dropped from 0.309 to 0.229 , and that of innovative spirit fell from 0.198 to 0.137 , reflecting that $R \& D$ investment mediated the relationship between entrepreneurship and REG. Thus, H3a and H3b were proved valid. In summary, entrepreneurial spirit and innovation spirit have a positive effect on REG; R\&D investment mediates the relationship between entrepreneurial or innovative spirit and 
REG. Hence, entrepreneurship is an important driver of economic growth. As shown in Table 2, in the current phase of economic development, the coefficient of capital stock's impact on REG was larger than that of any other factor. However, after the R\&D investment was added, the regression coefficient of capital stock dropped from 0.638 in Model 1 to 0.318 in Model 6, and from 0.733 in Model 2 to 0.442 in Model 7, despite remaining as the largest coefficient. This testifies the driving effect of innovation on economic development. In addition, the government regulation achieved the positive effect as expected, but the development of the deposit and loan market of financial institutions and the scale of FDI failed to fully satisfy the needs of current economic development. The level of human capital and infrastructure construction exerted significant positive impacts on the REG, but their coefficients were relatively small.

\subsubsection{Regional differences in the influence of entrepreneurship over REG}

Next, the differential impact of entrepreneurial and innovation spirits on REG was explored by comparing the situations in the three major economic regions of China, plus the intermediary role of R\&D investment. The specific results are shown in Tables 3 and 4 .

Table 3. The regional differences in the impact of entrepreneurial spirit on economic growth

\begin{tabular}{|c|c|c|c|c|c|c|}
\hline & (1) & (2) & (3) & (4) & (5) & (6) \\
\hline & East & Central & West & East & Central & West \\
\hline & Tgdp & Tgdp & Tgdp & Tgdp & Tgdp & Tgdp \\
\hline ln_Lf & $\begin{array}{c}0.338 * * * \\
(5.38)\end{array}$ & $\begin{array}{l}-0.027 \\
(-0.89)\end{array}$ & $\begin{array}{c}0.173^{* *} \\
(2.20)\end{array}$ & $\begin{array}{c}0.247 * * * \\
(4.58)\end{array}$ & $\begin{array}{l}-0.026 \\
(-0.88)\end{array}$ & $\begin{array}{l}0.085 \\
(1.25)\end{array}$ \\
\hline ln_Sc & $\begin{array}{c}0.794 * * * \\
(16.49)\end{array}$ & $\begin{array}{c}0.225^{* * *} * \\
(3.96)\end{array}$ & $\begin{array}{c}0.626 * * * \\
(15.23)\end{array}$ & $\begin{array}{c}0.384 * * * \\
(6.24)\end{array}$ & $\begin{array}{c}0.183 * * * \\
(3.10)\end{array}$ & $\begin{array}{c}0.335^{* * *} \\
(6.79)\end{array}$ \\
\hline ln_Pee & $\begin{array}{c}0.212 * * * \\
(7.13)\end{array}$ & $\begin{array}{c}0.474 * * * \\
(19.81)\end{array}$ & $\begin{array}{c}0.293 * * * \\
(12.45)\end{array}$ & $\begin{array}{c}0.175^{* * *} * \\
(6.90)\end{array}$ & $\begin{array}{c}0.444 * * * \\
(16.30)\end{array}$ & $\begin{array}{c}0.214 * * * \\
(9.66)\end{array}$ \\
\hline Ln_Rd & & & & $\begin{array}{c}0.258 * * * \\
(8.88)\end{array}$ & $\begin{array}{c}0.050 * * \\
(2.22)\end{array}$ & $\begin{array}{c}0.219 * * * \\
(8.44)\end{array}$ \\
\hline ln_Gov & $\begin{array}{c}0.539 * * * \\
(8.13)\end{array}$ & $\begin{array}{c}0.200 * * * \\
(3.33)\end{array}$ & $\begin{array}{c}0.125 * * \\
(2.44)\end{array}$ & $\begin{array}{c}0.253 * * * \\
(3.93)\end{array}$ & $\begin{array}{c}0.196 * * * \\
(3.32)\end{array}$ & $\begin{array}{c}0.077^{*} \\
(1.76)\end{array}$ \\
\hline ln_Fir & $\begin{array}{c}-0.173^{* *} \\
(-2.60)\end{array}$ & $\begin{array}{l}-0.015 \\
(-0.30)\end{array}$ & $\begin{array}{l}-0.057 \\
(-0.85)\end{array}$ & $\begin{array}{c}-0.198 * * * \\
(-3.53)\end{array}$ & $\begin{array}{l}-0.010 \\
(-0.21)\end{array}$ & $\begin{array}{l}-0.054 \\
(-0.96)\end{array}$ \\
\hline ln_Fdi & $\begin{array}{c}-0.069 * * * \\
(-3.29)\end{array}$ & $\begin{array}{c}-0.159 * * * \\
(-10.33)\end{array}$ & $\begin{array}{l}0.006 \\
(0.35)\end{array}$ & $\begin{array}{c}-0.039 * * \\
(-2.13)\end{array}$ & $\begin{array}{c}-0.156^{* * * *} \\
(-10.19)\end{array}$ & $\begin{array}{l}0.013 \\
(0.86)\end{array}$ \\
\hline $\mathrm{ln}_{-} \mathrm{Hc}$ & $\begin{array}{l}0.165 \\
(1.43)\end{array}$ & $\begin{array}{l}0.142^{*} \\
(1.81)\end{array}$ & $\begin{array}{l}-0.004 \\
(-0.04)\end{array}$ & $\begin{array}{l}0.074 \\
(0.76)\end{array}$ & $\begin{array}{l}0.124 \\
(1.60)\end{array}$ & $\begin{array}{l}-0.006 \\
(-0.06)\end{array}$ \\
\hline ln_Il & $\begin{array}{l}-0.011 \\
(-0.40)\end{array}$ & $\begin{array}{c}0.057^{*} \\
(1.94)\end{array}$ & $\begin{array}{c}0.150 * * * \\
(3.19)\end{array}$ & $\begin{array}{c}-0.045^{*} \\
(-1.85)\end{array}$ & $\begin{array}{l}0.042 \\
(1.40)\end{array}$ & $\begin{array}{c}0.118^{* * * *} \\
(2.92)\end{array}$ \\
\hline cons & $\begin{array}{c}-1.395^{* *} \\
(-2.34)\end{array}$ & $\begin{array}{c}6.242 * * * \\
(12.79)\end{array}$ & $\begin{array}{l}1.139^{*} \\
(1.83)\end{array}$ & $\begin{array}{c}2.356^{* * * *} \\
(3.59)\end{array}$ & $\begin{array}{c}6.445 * * * \\
(13.16)\end{array}$ & $\begin{array}{c}3.524 * * * \\
(5.85)\end{array}$ \\
\hline $\mathrm{N}$ & 209 & 152 & 209 & 209 & 152 & 209 \\
\hline $\mathrm{R}^{2}$ & 0.983 & 0.993 & 0.980 & 0.988 & 0.993 & 0.986 \\
\hline
\end{tabular}

According to the results of Models 1-3 in Table 3, entrepreneurial spirit had a significant positive impact on the economic growth of East, Central, and West China, and the coefficients of the impact were 0.212, 0.474, and 0.293, respectively. According to the results of Models 1-3 in Table 4 , the impact coefficients of innovative spirit on economic growth in East, Central, and West China were 0.133, 0.148, and 0.221 , respectively. Thus, the entrepreneurial spirit has the greatest influence on economic growth in Central China; the innovative spirit has the greatest influence on economic growth in West China; the impacts of both spirits on economic growth were minimized in East China. The main reason lies in the fact that East China is the most economically developed region of China, with solid economic foundation, strong early accumulation, and fast economic growth. It can also be seen that accumulative factors like capital stock had relatively large driving effect on economic growth. In addition, entrepreneurial spirit surpassed innovative spirit in the promotion of economic growth in all three regions.

Models 4-6 in Table 3 and Table 4 are empirical results after the addition of R\&D investment. After the addition, the impact coefficients of the two spirits remained significant, but their values became smaller. This means R\&D investment mediates the relationship between the two spirits and REG. The mediation role was the greatest in East China, and smallest in Central China. Comparatively, R\&D investment had a greater intermediary role in the influence of innovative spirit over REG than that of entrepreneurial spirit over REG.

\subsection{Robustness test}

Two methods were employed to test the robustness of the analysis results. From the perspective of variables, the first method tests the influence of the possible endogeneity between the explained variable and the explanatory variable on the statistical results, and verify the sensitivity of the results. From the perspective of data, the second method tests the significance and stability of the results through sub-sample regression. For the lack of space, the robustness test results are not provided here. Firstly, the main variables were replaced as follows: the RGDP was substituted by per-capita GDP, the number of employees in private enterprises as a percentage of the total number of employees was substituted by the selfemployment ratio or the ratio of private and self-employed households to the total number of employees, and the number of patent applications was substituted by the number of patent applications. The results show that the significance and direction of the variable coefficients basically remained the same. Secondly, the sample size of each PAR was reduced, and regression analysis was performed on the reduced data in 2009-2018. The results were still robust. 
Table 4. The regional differences in the impact of innovative spirit on economic growth

\begin{tabular}{ccccccc}
\hline & $(1)$ & $(2)$ & $(3)$ & $(4)$ & $(5)$ & $(6)$ \\
& East & Central & West & East & Central & West \\
& Tgdp & Tgdp & Tgdp & Tgdp & Tgdp & Tgdp \\
\hline ln_Lf & $0.315^{* * *}$ & -0.009 & 0.057 & $0.258^{* * *}$ & -0.008 & 0.002 \\
& $(4.86)$ & $(-0.19)$ & $(0.87)$ & $(4.35)$ & $(-0.16)$ & $(0.05)$ \\
ln_Sc & $0.782^{* * *}$ & $0.895^{* * *}$ & $0.698^{* * *}$ & $0.509^{* * *}$ & $0.729 * * *$ & $0.383 * * *$ \\
& $(14.57)$ & $(14.08)$ & $(22.35)$ & $(7.91)$ & $(8.90)$ & $(9.88)$ \\
ln_Paa & $0.133^{* * *}$ & $0.148^{* * *}$ & $0.221^{* * *}$ & $0.053^{* *}$ & $0.094 * * *$ & $0.180^{* * *}$ \\
& $(6.26)$ & $(7.26)$ & $(16.98)$ & $(2.33)$ & $(3.55)$ & $(16.24)$ \\
ln_Rd & & & & $0.244 * * *$ & $0.131^{* * *}$ & $0.211^{* * *}$ \\
& & & & $(6.50)$ & $(3.07)$ & $(10.58)$ \\
ln_Gov & $0.574^{* * *}$ & 0.023 & 0.034 & $0.357^{* * *}$ & 0.035 & 0.007 \\
& $(8.58)$ & $(0.23)$ & $(0.78)$ & $(5.17)$ & $(0.37)$ & $(0.20)$ \\
ln_Fir & -0.108 & 0.086 & -0.044 & $-0.137 * *$ & $0.154 *$ & -0.058 \\
& $(-1.60)$ & $(0.98)$ & $(-0.78)$ & $(-2.24)$ & $(1.74)$ & $(-1.32)$ \\
ln_Fdi & $-0.046^{* *}$ & $-0.095^{* * *}$ & $0.039^{* *}$ & -0.010 & $-0.104 * * *$ & $0.038^{* * *}$ \\
& $(-2.18)$ & $(-3.61)$ & $(2.57)$ & $(-0.53)$ & $(-4.05)$ & $(3.10)$ \\
ln_Hc & 0.064 & 0.045 & 0.0340 & 0.043 & 0.038 & 0.009 \\
& $(0.54)$ & $(0.34)$ & $(0.39)$ & $(0.40)$ & $(0.30)$ & $(0.13)$ \\
ln_Il & 0.016 & 0.046 & $0.135^{* * *}$ & -0.018 & 0.010 & $0.090^{* * *}$ \\
& $(0.53)$ & $(0.93)$ & $(3.43)$ & $(-0.66)$ & $(0.21)$ & $(2.84)$ \\
cons & $-2.427 * * *$ & -0.175 & -0.225 & 0.513 & $1.117 *$ & $2.551^{* * *}$ \\
& $(-4.50)$ & $(-0.35)$ & $(-0.46)$ & $(0.77)$ & $(1.73)$ & $(5.41)$ \\
N & 209 & 152 & 209 & 209 & 152 & 209 \\
$\mathrm{R}^{2}$ & 0.982 & 0.981 & 0.986 & 0.985 & 0.982 & 0.991 \\
\hline
\end{tabular}

\section{CONCLUSIONS}

Based on the panel data of 30 PARs in Chinese mainland in 2000-2018, this paper empirically analyzes the influence of entrepreneurship over R\&D investment and REG. The main conclusions are as follows:

(1) The entrepreneurial and innovative spirits of entrepreneurs promote REG; the promoting effect of entrepreneurial spirit is greater than that of innovative spirit. The entrepreneurial and innovative activities by entrepreneurs help to expand the scale of enterprises and markets, enrich innovation results, seize market opportunities, and enhance corporate competitiveness, thus promoting corporate growth and economic development.

(2) The entrepreneurial and innovative spirits of entrepreneurs boost R\&D investment and technological upgrade, thereby driving economic growth. R\&D investment mediates the influence of entrepreneurial and innovative spirits over REG. Entrepreneurs with entrepreneurial and innovative spirits can quickly identify and seize growth opportunities, and make timely adjustment to R\&D investment and resource allocation decisions. These contribute to the speed and quality of economic development.

(3) The three major economic regions of China, namely, East, Central, and West China, have different laws in the direct influence of entrepreneurial spirit and innovative spirit on economic growth, and the indirect influence via $R \& D$ investment. East China witnessed the minimum promoting effect of the two spirits on economic growth, yet the strongest intermediary effect of R\&D investment; Central China saw the maximum promoting effect of the two spirits on economic growth, yet the weakest intermediary effect of R\&D investment. The innovative spirit has the greatest influence on economic growth in West China.

(4) The coefficient of capital stock's impact on REG was larger than that of any other factor. Government regulation achieved the positive effect as expected, but the development of the deposit and loan market of financial institutions and the scale of FDI failed to fully satisfy the needs of current economic development. The level of human capital and infrastructure construction exerted significant positive impacts on the REG, but their coefficients were relatively small.

Based on the above results, the following countermeasures were proposed:

(1) China should create a favorable environment for the shaping of entrepreneurship, stimulate the vitality of entrepreneurship, and fully exert the promoting effect of entrepreneurship on REG. Considering the importance of entrepreneurship, the governments at all levels must unleash the influence of entrepreneurship on economic development, and cultivate entrepreneurship through spurring government expenditures and laying down intellectual property policies.

(2) China should strength the role of entrepreneurship on R\&D investment, encourage entrepreneurs to renew their mindsets, and take concrete actions in $R \& D$ investment, thereby exerting the mediating effect of $R \& D$ investment between entrepreneurship and REG. These efforts will promote technological innovation and progress, transform the economic growth mode, and improve the quality of economic development.

(3) China should gradually develop an economic development model involving multiple drivers, such as entrepreneurship, instead of relying on a single driving factor. The control factors like government intervention should also be continuously improved to enhance the guiding force of policies, and optimizing the role of policy instruments in promoting economic scale and quality. In addition, financial development should be improved to amplify the role of financial market in ensuring economic development. Furthermore, different regions should all improve the level and quality of human capital, especially West China, aiming to back up economic growth with high-quality manpower and professional knowledge. 
All in all, this paper fully explores the REG from the perspectives of entrepreneurship and R\&D investment. On this basis, the future research will strive to effectively allocate entrepreneurship, and coordinate entrepreneurship with other production factors, with the goal of ensuring REG under uncertain environments.

\section{ACKNOWLEDGEMENT}

This paper was supported by Heilongjiang Philosophy and Social Science General Project (19GLB084); Heilongjiang Provincial Undergraduate Universities Basic Research Business Expenses Research and Innovation Platform Project (135409435), and National Natural Science Foundation of China (71803095).

\section{REFERENCES}

[1] Beugelsdijk, S., Noorderhaven, N. (2004) Entrepreneurial attitude and economic growth: a grosssection of 54 regions. The Annals of Regional Science, 38(2): 199-218. https://doi.org/10.1007/s00168-0040192-y.

[2] Kružić, D. (2007). Entrepreneurship and economic growth: Re-actualisation of the role of entrepreneurship in global economy. Ekonomska Misao I Praksa, 2: 167191.

[3] Toma, S.G., Grigorea, A.M., Marinescu, P. (2014). Economic development and entrepreneurship. Procedia Economics and Finance, 8: 436-443. https://doi.org/10.1016/S2212-5671(14)00111-7

[4] Freeman, S., Zhu, Y., Warner, M. (2020). International Entrepreneurship: A Comparative Analysis. Routledge. https://doi.org/10.4324/9781351109673

[5] Xabibullayevich, U.L., Nabijanovich, B.D., Ibragimovna, F.E. (2020). Increasing effectiveness of economic education process is basis for the development of qualification of entrepreneurship. Asian Journal of Multidimensional Research, 9(3): 210-215. https://doi.org/10.5958/2278-4853.2020.00085.3

[6] Hela, M., Daniele, S. (2017). Innovation and entrepreneurship for the diversification and growth of the Gulf Cooperation Council Economies. Business and Management Studies, 3(3): 69-81. https://doi.org/10.11114/bms.v3i3.2594

[7] Hashi, I., Krasniqi, B.A. (2011). Entrepreneurship and SME growth: evidence from advanced and laggard transition economies. International Journal of Entrepreneurial Behavior \& Research, 17(5): 456-487. https://doi.org/10.1108/13552551111158817

[8] Hébert, R.F., Link, A.N. (1989). In search of the meaning of entrepreneurship. Small Business Economics, 1(1): 39-49. https://doi.org/10.1007/BF00389915

[9] Mthanti, T., Ojah, K. (2017). Entrepreneurial orientation (EO): Measurement and policy implications of entrepreneurship at the macroeconomic level. Research Policy, 46(4): 724-739. https://doi.org/10.1016/j.respol.2017.01.012

[10] Lee, Y.S. (2016). Entrepreneurship, small businesses and economic growth in cities. Journal of Economic Geography, $\quad 17(2)$ : 311-343. https://doi.org/10.1093/jeg/lbw021

[11] Djankov, S., Qian, Y., Ronald, G., Zhuravskaya, E. (2006). Who Are China's Entrepreneurs? American Economic Review, 96(2): 348-352. https://doi.org/10.1257/000282806777212387

[12] Adusei, M. (2016). Does entrepreneurship promote economic growth in Africa? African Development Review, 28(2): 201-214. https://doi.org/10.1111/14678268.12190

[13] Belitski, M., Desai, S. (2016). Creativity, entrepreneurship and economic development: City-level evidence on creativity spillover of entrepreneurship. The Journal of Technology Transfer, 41(6): 1354-1376. https://doi.org/10.1007/s10961-015-9446-3

[14] Guellec, D., Van Pottelsberghe de la Potterie, B. (2004). From R\&D to productivity growth: Do the institutional settings and the source of funds of R\&D matter? Oxford Bulletin of Economics and Statistics, 66(3): 353-378. https://doi.org/10.1111/j.1468-0084.2004.00083.x

[15] Baumol, W.J. (1996). Entrepreneurship: Productive, unproductive, and destructive. Journal of Business Venturing, 11(1): 3-22. https://doi.org/10.1016/08839026(94)00014-X

[16] Kaur, M., Singh, L. (2016). R\&D expenditure and economic growth: An empirical analysis. International Journal of Technology Management \& Sustainable Development, 15(3): 195-213. https://doi.org/10.1386/tmsd.15.3.195_1

[17] Freire-Seren, M.J. (2001). R\&D-expenditure in an endogenous growth model. Journal of Economics, 74(1): 39-62. https://doi.org/10.1007/BF01231215

[18] Djankov, S., Qian, Y., Roland, G., Zhuravskaya, E. (2006). Who are China's entrepreneurs? American Economic $\quad$ Review, 96(2): 348-352. https://doi.org/10.2139/ssrn.893324

[19] Aghion, P., Howitt, P. (1992). A model of growth through creative destruction. Econometrica, 60(2): 323351. https://doi.org/10.2307/2951599

[20] Herra, R., Long, Z.M. (2016). Building original series of physical capital stocks for China's economy (1952-2014). China Economic Review, 40: 33-53. https://doi.org/10.1016/j.chieco.2016.05.002 